\title{
Student-Centeredness in Social Science Textbooks, 1970-2008: A Cross-National Study*
}

Patricia Bromley, John W. Meyer, and Francisco O. Ramirez

School of Education/Department of Sociology, Stanford University

* Work on this paper was funded by a grant from the Spencer Foundation (200600003) to Francisco Ramirez and John Meyer. The study was possible only because of the impressive textbook collection of the George Eckert Institute, in Braunschweig, and the extraordinarily helpful assistance Brigitte Depner and her staff gave us.

Correspondence should be directed to the attention of: Patricia Bromley, Stanford University, Stanford, CA 94305: email triciam@stanford.edu 


\title{
Student-Centeredness in Social Science Textbooks, 1970-2008: A Cross-National Study
}

\begin{abstract}
A striking feature of modern societies is the extent to which individual persons are culturally validated as equal and empowered actors. The expansion of a wide range of rights in recent decades, given prominence in current discussions of world society, supports an expanded conception of the individual. We examine the extent to which broad global changes promoting human empowerment are associated with expanded ideas of the status and capacities of students. We hypothesize that there are substantial increases in student-centered educational foci in countries around the world. First, the rights of students as children are directly asserted. Second, an emphasis on empowered human agency supports forms of socialization that promote active participation, and the capacities and interests of the student. Examining a unique data set of 533 secondary school social science textbooks from 74 countries for the period since 1970, we find that textbooks have indeed become more student-centered, and that this shift is associated with the rising status of individuals and children in global human rights treaties and organizations. Student-centered texts are more common in countries with greater individualism embodied in political and socioeconomic institutions and ideologies, and with more links to world society. The study contributes to both political and educational sociology, examining how global changes lead to increased emphases on empowered individual agency in intended curricula.
\end{abstract}


Many social changes, operating on a global scale over several centuries, have led to the cultural validation of individual persons as key actors in human societies (Lie 2004; Carrithers et al. 1985). This worldwide development intensified after World War II, and in the recent period, in response to actual and perceived global interdependence in economic, political, and social arenas. It reflects an ideology of development and modernization that emphasizes the capabilities of individuals (as in human capital notions or more recent emphases on innovation and entrepreneurship), and thus the socialization of children toward agentic social participation (Meyer and Jepperson 2000). The rise and expansion of mass schooling is an important long-term institutional manifestation of this ideology: State after state established compulsory school laws, created national educational ministries, and joined in a world educational revolution expanding enrollments and escalating expectations of education as a "silver bullet" for the production of social and economic progress (Baker and LeTendre 2005). This vision of progress is evolving from its roots in national citizenship toward a globally celebrated personhood in a world society (Ramirez 2006; Meyer et al. 1997). The right to an elementary education is now heralded as a universal human right (Universal Declaration of Human Rights 1948, Article 26), no longer linked to social contracts between national states and citizens.

As children are to become active sources of national and world social and economic progress, schools are increasingly expected to provide students with opportunities for self-expression and development. The ideal student is envisioned as an active and engaged learner, not a disciplined subordinate (Arum 2003). The extraordinary agency imputed to adults in much theory and ideology is now extended to youth. Sociologists from Durkheim to Goffman have reflected on the construction of the agentic (even deified) individual. The extension of this dynamic perspective to young learners adds up to a vision of progress in which the student is central, as in phrases like "active learning," "learning to learn," "lifelong learning," the "right to learn," and the "learning society." This educational repertoire is known worldwide and resonates with the agendas of many domestic and international organizations, from Save the Children to the World Bank (Jakobi 2009). 
The vision of the expanded rights and upgraded capabilities of students has obvious implications for what and how students are taught about their societies. Both the content and the format of intended curricula may evolve to make the active student central. Concretely, we should observe more user-friendly and active-learning emphases in textbooks. And, if this changing vision is global, we should see global change toward greater student-centeredness. The broad vision of social and economic progress as rooted in an expanded and agentic individual has attracted much interest across a broad spectrum, from those who celebrate individual freedom to those who fear its excesses. But in political and cultural sociology, debates have not mainly focused on schooling, much less the curriculum. The issues arise, but only indirectly, in the sociological study of the "hidden curriculum" (Bowles and Gintis 1976; Dreeben 1968).

We study empirically this core issue - the rise of student-centered education - by examining many social science textbooks from many countries over recent decades. Most lines of argument, like those stressed here, emphasize the enhanced individualism built into modern and post-modern economy, society, and culture, with their conceptions of social and economic progress as rooted in individual enterprise. A few critical lines of thought emphasize the extensive social controls involved - the "colonization of the lifeworld" theme (Habermas 1987), compulsory education (Goodman 1960; classically Illich 1971), or notions of education as disciplining the lower or laboring classes (Bowles and Gintis 1976). Even conservative analyses stress the expansive individualism and student-centrism of the modern system (Bloom 1987; Ravich 1987). More recent discussions of the impact of capitalism and its requirements shift from foci on labor control to celebrations of the importance of individual enterprise (contrast Spring 1980 with the recent literature).

We conduct a direct investigation, looking comparatively and longitudinally textbooks from countries around the world. Textbooks, commonly developed by world-certified professionals, and approved at national or intra-national regional levels, reflect intended curricula, and thus institutionalized notions of 
social reality. Indeed, the curriculum is a key site where what counts as knowledge is established and transmitted, and changes in it, whatever their socializing effects, are indicators of basic cultural changes.

We address the issue of the expansion and empowerment of students, worldwide, by focusing on a unique and extensive collection of 533 junior and senior secondary social science textbooks from 74 countries. In related work we analyze the global rise of human rights education and of environmentalism (Meyer et al 2010; Bromley et al 2011). In this paper we focus on student-centrism and its association with broad global cultural changes emphasizing human empowerment.

We investigate three interrelated questions relevant both to the sociology of education and the study of modern culture. First, does increased student-centrism follow changed world emphases? The worldwide testing regime, one could imagine, might emphasize narrow curricular content instead of student centrism. Or, perhaps we should expect to find sharp differences across countries. However, if the status of the child and student has been upgraded worldwide, we may find a worldwide trend in favor of studentcentric textbooks.

Second, is student-centrism especially reflective of liberalism in political culture and economic ideology? Or, is national heritage less relevant given the rapid diffusion of westernizing educational blueprints? Finally, is student-centrism especially evident in books from countries closely integrated with a world society that validates student empowerment, and makes it a crucial source of all sorts of progress? Recent studies recognize that intended national curricula are more open to regional and global influences than in past eras (e.g. Benavot and Braslavsky 2006.)

In what follows we first clarify our motivating theoretical perspective. Next we describe our textbook data and indicate how we measure textbook levels of student centeredness and the independent variables that 
reflect world and national properties. We then report the results of our multi-level analyses. Lastly, we discuss the sociological implications of our findings.

\section{Background}

Traditional societies tend to locate the roots of stability and change in collective social and supra-social forces, such as political and religious elites, the gods or fates (Durkheim [1911]1965; Swanson 1967). They do not much celebrate the individual, or see the individual as the source of society, and rather imagine that individuals will learn their roles through their subordination to ongoing family and society. Thus, they do not organize systems of mass education, and any elite schooling they do organize tends to subordinate the individual to the sacred texts of a collective order - the texts, rather than the students, lie at the center of schooling.

The expansion and dominance of modern models of society as rooted in autonomous individuals, on the other hand, makes the production of agentic individuals central to social stability and progress. Mass education becomes a central institution (Dreeben 1968; Meyer 1977), and increasingly attends to the interests, choices, and comprehension of the student. This tendency increases with the rise of models of a global society built around expanded notions of the rights and powers of the human individual (Meyer et al. 1997).

Individual Rights: In the post-War period, the rights of individuals - including youthful individuals change in character, reflecting the aggressive liberalism of the dominant global climate. The individual, rather than the community or the national state and society, comes to be seen as the driving force of social and economic development. Political democracy, open market economics, and cultural freedom are all to be built on the choices of empowered individual persons, and the perspectives of these individuals come to be highly legitimated. In such a society, now ideologically envisioned worldwide, expanded education 
for individual development (rather than, for example, social needs) becomes a basic good, and education expands dramatically in every sort of country in the world (Schofer and Meyer 2005; Meyer et al. 1992a). In this world society, education comes prominently to include human rights education - the subject of a major educational movement in recent decades (Ramirez et al. 2006; Suárez 2007). It becomes a goal of educational systems everywhere (see Rosenmund 2006 for a review), justified in terms of broad notions of socio-economic development, and thus political, social and economic elites subscribe to it. And it becomes part of the educational process itself, as student choices of schools and programs and courses and projects expand everywhere (for higher education, see Frank and Meyer 2007; for mass education see the papers in Benavot and Braslavsky 2006).

The rights of children are given much attention in this history: the long-term rise of individualism is closely linked to the expanded status of children (Aries 1962; Zelizer 1985; Ramirez 1989). If the individual is the crucial social element, the socialization of the child becomes central. Thus, constitutional statements of the rights of children expand dramatically, in every sort of country (BoliBennett and Meyer 1978). Both the right to education and the compulsory obligation to pursue it become world-wide and explicitly elaborated as global in statements of the Education for All and Universal Basic and Secondary Education movements (Chabbott 2003). Many of the global human rights treaties and instruments assert the rights of children (Elliott 2008; Boli and Elliott 2008). They emphasize quite comprehensive rights, such as the right to early childhood care and education, as in the United Nations Convention on the Rights of the Child (United Nations 1989).

The Progressive Pedagogy: Throughout the long history of the expansion of individualism and of human rights, these movements have been closely linked to education, and to particular doctrines about education. As individuals are re-conceptualized as possessing the inherent right and capacity to make a range of social, economic, and cultural choices, the appropriate nature of education changes in character. In very traditional educational forms, in which persons are being inducted into the arena of fixed elite 
culture, education is likely to take highly rigid, authoritarian and ritualized forms (see Zborowski 1995, or studies of traditional Chinese schooling [Tseng 1966], for accounts of education in such contexts). The psychology involved in this sort of schooling is likely to be quite limited.

In modern but illiberal educational forms, in which the student is being inducted into an authoritative society and economy, a more limited educational psychology can appear. The adult culture to which the student is being socialized should go through a process of translation to be structured in a pedagogically rational and correct sequence (see Cohen 1962 for an account of this development in mathematics instruction, or Bowles and Gintis 1976 and Spring 1980 for accounts of capitalist pressures for labor control). The role of the teacher as pedagogical authority becomes central. In these forms, growth potential is not a diffuse matter of personal development, but involves more limited classroom experience centered on the teacher and the teacher's control. But in the most liberal modern educational forms the student becomes central in two ways, and progressive pedagogies have become ideologically dominant on a world scale. First, training the student to become an autonomous choosing adult naturally requires providing the appropriate experience and practice (Torney-Purta et al. 2001). So the school should be a microcosm of the society and economy built around individual choices and interests. Second, in modern theory and culture, the student as child is already an entitled and empowered person, with interests and capacities and rights to have preferences, tastes, and choices. So the school, as part of modern society, must reflect a student-centered world.

Throughout the whole modern period, the great names of educational theory emphasize precisely these points (e.g., Humboldt; Dewey; Freire), and the doctrines involved have become conventions in the thinking in Ministries of Education everywhere (Rosenmund 2006). It is hard to find prominent advocates of the most traditional educational forms (e.g., the Zen-like virtues of forcing students to memorize material they do not understand). It is easier to find advocates of the less liberal modern forms 
- proponents of vocational education for particular roles, or of coerced instruction in cultural canons - but they are not really central to main educational developments (Benavot and Amadio 2005).

\section{Hypotheses}

Many forces in contemporary society work for education organized around the choices and interests of students as persons - here termed "student-centered" education. Our research investigates the extent to which themes of this sort appear in social science textbooks around the world. We approach the textbooks with the following ideas:

Hypothesis 1: Textbooks have become more student-centered in the decades since 1970, reflecting an expanded and individual rights oriented liberal world society.

Hypothesis 2: Textbooks from countries more closely tied to contemporary world society tend to be more student-centered.

Hypothesis 3: Textbooks from countries emphasizing individualism in political, economic, and cultural ideologies tend to be more student-centered.

We examine these hypotheses in multivariate and multi-level analyses with controls for other obvious independent variables, such as national socio-economic development and world region.

\section{Data}

Finding Books: On a cross-national basis, educational enrollment information has been tracked by international bodies for many decades and is very widely available. It seems to matter to the world 
whether young persons are enrolled in schools at various grade levels. But information on aspects of the actual or intended content of education has received much less attention, and curricula are generally poorly tracked and recorded (Meyer et al. 1992b), particularly over time. One exception is the research on mathematics and science curricular frameworks related to the Third Mathematics and Science Studies, and follow-up, investigations. Baker and LeTendre (2005) provide an informative summary of these studies. Important in their own right, these studies do not give attention to the societal and transnational sources of curricular variations and trends. One can often find ministerial reports defining the current intended curriculum, but historical documents are rarely kept. The most extensive historical and crossnational data are found in the collections of the International Bureau of Education (see the uses in Benavot and Amadio 2005 and Meyer et al.1992b), but these describe half or fewer of the world's educational systems, and sketch out curricular categories in the most limited way.

The limited availability of data is even more extreme insofar as textbooks are concerned. With some effort, one can find currently approved textbooks, but it is even difficult to obtain lists of approved books for earlier periods and outmoded books are rarely preserved. The best textbook collection we could locate is in the library of the Georg Eckert Institute for International Textbook Research in Braunschweig, Germany. The Institute was founded after the Second World War with the explicit aim of collecting, studying, and reforming social science curricula and textbooks to move them away from the nationalism thought to have generated the crises and tragedies of the first half of the twentieth century. The outcome of this effort is a library with over 60,000 social science school textbooks, mainly history, civics, social studies, and geography, principally for the period since 1950 .

By working with the staff of the Eckert Institute library, and by adding textbooks for additional countries supplied by colleagues around the world - we have systematically coded 533 history, civics, and social studies textbooks for 74 countries for the period from 1970 to the present. We focused on junior and senior secondary texts (i.e., those aimed at grades 6 through 12), and first selected books from countries 
with a minimum of two books per time period (one history and one civics or social studies text in each period) at the Eckert Institute. Despite the efforts at the Institute, European and North American countries were over-represented. In a second phase of selection, aimed at gathering books from other regions, we relied on the support of colleagues from around the world. Overall, for 27 countries we were able to find at least one textbook in each period. For 19 countries, we obtained textbooks for only one period although in a number of cases this is due to the country only coming into existence part way through the study. Appendix A provides a list of the countries covered by our data set, and the number of books we could find and code for each country in each period. Since we have varying numbers of textbooks for countries and periods, we employ a hierarchical linear model, in our analyses, to handle the problem. Seven books from the Palestinian territories had to be excluded from the hierarchical models due to a lack of country-level data, but they are included in the initial descriptive analyses.

Each book was coded using a simple scheme (available from the authors) designed to capture student centrism and other relevant variables such as human rights emphases and international orientation. On average, an hour per book was needed to code for the variables of interest. The coding was done, or supervised, by members of our research group. In many cases, of course, the textbooks were in languages we do not know, so we found and worked directly with coders fluent in the relevant languages. In the course of developing our coding scheme we monitored inter-coder reliability. This was not a major problem, since our coding scheme was straightforward and factual in character, and called for little difficult interpretation.

The result of our effort is a completely unique data set, covering a great many more books, countries and time periods than any previous studies. We can, thus, make many more comparisons across countries and over time than have previously been possible. Of course, we do not have comprehensive sets of textbooks for any given country, period, level of schooling, and subject area. In four country cases we have simply a single book. We do not have data on how heavily the books we have coded were in fact 
used. Further, we do not know how much the subject area covered by a book was emphasized in a country, though in most countries textbooks are strongly influenced by national curricular frameworks. While our data cover many more countries than any previous data set, they still include less than half of the extant countries of the world. In this kind of investigative research a degree of selection bias is inevitable. Our findings, thus, can be generalized only with caution: on the other hand, the consistent character of our results across different types of countries certainly encourages some generalization.

\section{Measures}

Dependent Variable: Our empirical analysis focuses on a single dependent variable characterizing textbooks, which we label "student-centrism." We wanted to find indicators that reflected the degree to which the textbook appealed to the student's interests, capacities, and choices. So textbooks were coded on the following eight items, on the scales indicated: (a) Presence (and frequency) of pictures, especially those likely to interest students (e.g., pictures of ordinary persons, or of young people), 0-3. (b) Presence and extent of any assignments for students, 0-2. (c) Presence and extent of active project activities for students, 0-2. (d) Presence and extent of role-playing exercises, 0-2. (e) Extent to which questions for students are open-ended, legitimating the student's own opinions and choices, without right-wrong answers, 0-3. (f) Extent to which the book is laid out in an "expanding environment" style, working from child to community to society, 0-3. Books were also coded on (g) the extent to which children are discussed in the text (0-5), and (h) whether children's rights are mentioned (0-1).

These eight items are substantially intercorrelated. With the exception of the extent to which children are discussed and whether children's rights are mentioned, the polychoric correlations range from 0.21 to 0.82. A factor analysis showed that the items load substantially on a single dimension, and the items were combined into a scale by using regression scoring to generate the appropriate factor weights. Cronbach's 
alpha for the overall Index is 0.72. A few examples illustrate the range of student-centrism found in textbooks.

\section{Highly Student Centered}

A highly student-centered book tailors content to the learner's developmental stage and contains many activities, projects, and questions designed to help students actively construct knowledge. For example, in a civics textbook for Guatemalan middle-school students, Figure 1, there are pictures on every page, and nearly all are photos of children or everyday life or colorful cartoon characters. In addition, substantive discussions of children and their rights run throughout the book. This page tells the Guatemalan students that it is time to discover the plight of the children of Poland during World War II by reading a personal account. The aim is to get the learner emotionally engaged, not simply to memorize facts of the war.

[Figure 1 about here.]

\section{Low Student Centrism}

At the other end of the student-centrism spectrum, books that are the lowest on the scale often have the flavor of sacred texts, consisting mainly of canonical information to be memorized. There are few questions, activities, pictures or projects, and the questions that do exist are designed to test whether students have absorbed information correctly. The rare pictures or figures in these texts are maps, photos of historical persons, monuments or landmarks, or charts. A Kenyan Form 3 book shown in Figure 2 has a number of illustrations, but they are all of historical figures and monuments. This book, entitled "Milestones in History and Government," is very much a traditional history book. The whole book has only about two dozen pictures, and almost all are of national historical figures, as shown in Figure 2 
below. Other figures include a picture of the Parliament building and a number of maps. There are activities and exercises in each chapter, but these are mostly questions with right and wrong answers such as "Identify four political associations in Kenya up to 1940" (p. 124).

[Figure 2 about here.]

To summarize, our examination of these textbooks reveals that there is considerable cross-national and within-country over-time variation in student-centrism. Further, the variation involves multiple dimensions of what might generally be regarded as student-centric emphases in curricula.

Independent Variables: Our first hypothesis proposes that textbooks become more student-centered over time, reflecting the global rise of foci on the individual and human rights and capacities. One obvious indicator is publication date. But a more relevant measure characterizes the global context. Drawing on previous research, we construct an index from five measures. Four of the items capture the context of the global human rights movement and status of children within the movement - (a) the cumulative number of human rights treaties worldwide (Elliott 2008), (b) the cumulative number of national human rights institutes worldwide (Koo \& Ramirez 2009), (c) the total number of human rights treaties that mention children's rights (Elliott 2008), and (d) the cumulative number of types of children's rights mentioned in human rights treaties (Elliott 2008). The fifth correlated measure is a count of the number of international non-governmental organizations (in thousands) in existence in the year of publication of a book. This and related variables are commonly used in comparative research to capture the rise of a more global society in the modern period (e.g., Suárez 2006, Schofer and Meyer 2005). The five items have a Cronbach's alpha score of 0.75 and load heavily onto a single factor. These measures are correlated with each other at over a 0.90 level and we combine them into a single index using regression scoring. Reinforcing our observation that publication date is a proxy for these global changes, all five measures also correlate with year at a level of 0.92 or higher. 
We also include two more indirect indicators, characterizing the book rather than the global context.

First, we note whether the textbook is a history text, rather than a civics or social studies text. Previous research suggests that the broad worldwide shift to a focus on the individual human person in world, rather than national, society has affected a general decline in instruction in history along with a rise in instruction in social science/social studies (Wong 1991, Benavot and Resh 2001). We have no measure of national curricular focus in our textbook data set, but we include a dummy variable for history textbooks to capture the effects of this broad change in our data set. Second, we approach the broad curricular change toward a more "social issues" approach by coding books on whether they deal with issues of everyday life, like handling money, dating, or family relations, rather than focusing mainly on the political and military history and the structure of society.

Our second hypothesis suggests that linkages to world society will co-vary with, and positively influence, student-centrism. We employ a conventional measure in world society research, the log of national memberships in international non-governmental organizations. We use the mean value for each country over the period of the study. ${ }^{1}$ This indicator is taken from the various years of Yearbook of International Organizations published by the Union of International Associations and is discussed at great length in Boli and Thomas (1999). This measure has shown positive influences on related dependent variables, such as the extent to which a human rights emphasis is found in textbooks (Meyer et al. 2010).

\footnotetext{
${ }^{1}$ A limitation of our approach is that HLM requires time-invariant observations at level-2. We consider whether changes over time in country-level indicators influence our results in two ways. First, we test both a point estimate at 1980 and a measure that is the average over the period of the study for GDP, democracy and INGO memberships. Our key findings are unchanged. Second, we treated country level properties as characteristics of books and allowed them to vary over time. The results of these models are not directly comparable to the analyses where country properties are time-invariant, but provide a rough check of our results. We found that when entered as time-varying properties at level-1, GDP and INGO memberships had positive and significant effects if entered alone, and positive and insignificant ones if added together. The direction and significance of our individualism index, regional controls, and book level variable effects were unchanged. Thus our core arguments are not substantially challenged by variation over time in country-level factors.
} 
Our third hypothesis suggests student-centrism is high in the centers of ideological individualism conceptions of social, political, and economic life as deriving from the choices and capacities of individuals. We explore three related indicators, taken from discussions in the literature: First, we create a measure of the prevalence of the academic field of psychology in a country using data from Frank et al. (1995). This measure includes counts of the logged numbers of psychologists per million in 1980 and 1992, the number of university psychology departments per thousand circa 1993, the logged number of developmental psychology articles and other psychology articles per capita published 1972-1989, and the logged number of memberships in international psychological associations in 1988. The items are combined into a continuous index using factor analysis. ${ }^{2}$ Second, we take a measure of political democracy ranging from -10 (strongly autocratic) to +10 (strongly democratic) (Marshall 2007). Specifically, we use a country's mean score over the period of our study. Third, as a measure of capitalist ideology we consider a country's score on an Index of Economic Freedom in 1995 (Heritage Foundation 2011). ${ }^{3}$ The Economic Freedom Index ranges from a low score of zero to a high of one hundred and consists of ten equally-weighted measures including business freedom, trade freedom, fiscal freedom, government spending, monetary freedom, investment freedom, financial freedom, property rights, freedom from corruption, and labor freedom. ${ }^{4}$ We combine the three measures, of psychology, democracy, and capitalist ideology, by summing the z-scores to create our index of cultural, political, and economic individualism.

Control Variables: In exploring our hypotheses, we control a number of other factors:

\footnotetext{
${ }^{2}$ The prevalence of psychology is highly correlated with all other cross-national measures of individualism (details available from authors).

${ }^{3}$ We thank an anonymous reviewer for suggesting we adopt a measure of capitalist ideology in our analysis.

${ }^{4}$ We recoded one extreme outlier, North Korea, from a score of 8.9 to the next lowest value of 29.4 (Bosnia and Herzegovina). The first year the Economic Freedom Index is available is 1995, for countries that dissolved prior to this we assigned the following: Czechoslovakia received the score for the Czech Republic, West Germany received the score for unified Germany, Yugoslavia received the score for Serbia, and the USSR received the score for the Russian Federation.
} 
Earlier sociological arguments often discuss the rise of individualism as a functional consequence of socioeconomic development, or as a prerequisite for development Much of the modernization literature had this emphasis (e.g., Lerner 1963, Inkeles and Smith 1974). This line of thought is given less emphasis in recent periods (see, e.g., Thornton 2005, who sees the relationship as cultural or ideological rather than functional). In our analyses, we incorporate a control for log GDP/capita using data from the World Bank's World Development Indicators (2008), as is conventional in cross-national, quantitative studies.

We also control for the common idea that modern curricula expand a great deal, and incorporate more material along every sort of theme. So we hold constant the number of pages in a textbook. We also control for the grade level at which a text is targeted, distinguishing senior secondary school texts, since it is likely that more advanced books have a more academic cast and are lower on student-centrism. Given the nature of book publishing, it is also plausible that books produced solely by for-profit companies are motivated to create textbooks that appear student-centered in order to appear more marketable. Thus, we include a dichotomous variable for whether the content of a book is controlled directly by the government versus private publishers. Finally, we characterize countries by their world regional location, as is common in cross-national research.

\section{Analyses}

We present simple means and percentages, and then shift to a hierarchical linear model (Raudenbush and Bryk 2002). Hierarchical models are appropriate because we hypothesize that the level of student centrism in textbooks is influenced by both textbook-level and country-level variables, and these textbooks are clustered by country. Modeling the outcome as only a product of textbook level variables using OLS regression underestimates the error that arises from the commonalities of textbooks within 
particular countries. Hierarchical models incorporate both textbook-level and country-level error, and allow us to use the fullest range of information available.

Our hierarchical model consists of a textbook level (level 1) equation and a country-level (level 2) equation. The constant of the textbook level equation is modeled as a function of country characteristics. We construct the variables such that the intercept in the level 1 equation is equal to the expected outcome in an average textbook (i.e. one whose value on all textbook level predictors is equal to the sample mean). ${ }^{5}$ The equations for one of our final models (Model 7 in Table 2) are:

(1) Score on Student Centrism Index $=\beta_{0}+\beta_{1}$ (Global Individualism Index $)$

$+\beta_{2}$ (History Textbook)

$+\beta_{3}$ (Book Addresses Social Science Issues)

$+\beta_{4}(\log$ Number of Pages $)$

$+\beta_{5}$ (High Grade)

$+\beta_{6}$ (Private Publisher)

$+\mathrm{r}_{\mathrm{ij}}$

(2) $\beta_{0}=\gamma_{00}+\gamma_{01}(\log$ INGO memberships)

$+\gamma_{02}$ (National Individualism Index)

$+\gamma_{03}(\log$ GDP/capita $)$

$+\gamma_{04}($ Eastern Europe)

$+\gamma_{05}$ (Middle East \& North Africa)

$+\gamma_{06}($ Latin America \& Caribbean $)$

$+\gamma_{07}($ Other Non-West Regions $)+\mu_{0 \mathrm{j}}$

\section{Results}

In Table 1, we show how our indicators of student-centrism vary over time-a core focus of Hypothesis 1.

[Table 1]

\footnotetext{
${ }^{5}$ We accomplish this through grand mean centering all level-1 variables. At level 2, continuous variables are grandmean centered and dichotomous variables are uncentered.
} 
The results are very clear. Every indicator of student-centrism in our data shows a substantial increase over the period since 1970, most strongly in the most recent decade. Indicators for an expanding environments format and mentions of children's rights show moderate decline in the middle period, but increase sharply since 1995 in line with the overarching trend. And of course, the overall index of these indicators shows a strong increase. Further, in Table 1, we show the mean student-centrism scores, over time, for books from several types of countries. These data show quite consistent increases over time in student-centrism across world regions. They also reveal some regional variations. As might be hypothesized, communist and formerly communist countries of Eastern Europe, and the Islamic countries of the Middle East and North Africa, score somewhat lower than countries in other regions. However, Western countries do not display higher levels of student centrism than the countries of Latin America and the Caribbean, Asia, or Africa. It is plausible that the modern global professional pedagogical emphasis on student-centrism has additional freedom to operate in new or dependent educational contexts. In any case, the regional differences are substantial enough to lead us to control regional variation in our multivariate analyses. ${ }^{6}$

Finally, in Table 1, we show the expected over-time declines in proportion of the textbooks that focus on history, compared with social studies (though our data set is not in any sense a real sample on this issue), and the increase in proportion of books that focus on social issues. These trends are consistent with other cross-national educational trends. The degree of official curricular time allocated to history has declined in lower levels of schooling (Wong 1991). In higher education history curricula also shift to become more oriented to social than to political and military topics (Frank and Gabler 2006).

We turn now to multivariate - HLM - analyses, which are reported in Table 2.

\footnotetext{
${ }^{6}$ We distinguish between the West (Western Europe plus the United States, Canada, Australia and New Zealand), Latin America and the Caribbean, the Middle East and North Africa, Eastern Europe and Other Non-West Countries (East Asia, South Asia, Africa, and Israel).
} 
[Table 2]

We begin with Model 1, showing simply our controls at the textbook level. As we might expect, textbook length shows a modest negative association with student-centrism. Similarly, we control for the grade level of the textbook, and as could be anticipated, textbooks for senior secondary school tend to be less student-centered. Books published by private, for-profit companies appear to be marginally more student-centered than those whose content is more directly controlled by the government, but this effect disappears once our substantive measures are added. Note also that the proportion of variance in student centrism explained by these textbook level controls is just $7 \%{ }^{7}$

Model 2 includes our first core substantive variable, an index of global individualism, and indicates that books reflecting the growth of global pressures for individual and student rights indeed are more studentcentric in content and format. This finding is consistent with the central hypothesis of our study, that world-level changes substantially impact national-level curricula. Note too that the size of this effect is rather large: The proportion of variance explained jumps to $23 \%$ with the addition of our global individualism index. In other analyses not reported here, we examine the impact of a simple measure of time on our dependent variable: it shows a similar, but slightly weaker, association than our substantive measure of the global context reported in Model 2.

Model 3 adds two further book-level measures. As hypothesized, history books have less studentcentrism, and books that address social issues like money or dating have more. So the world-level shift away from history instruction documented in other research, we infer, increases student-centrism. These data reinforce our hypothesis about overall global effects on national curricular culture. The results

\footnotetext{
${ }^{7}$ The exact meaning of $\beta_{0 \mathrm{j}}$ changes with the addition of textbook level predictors. Thus, results of level 2 proportion of variance explained statistics are only interpretable for the same level 1 model. For this reason we do not report proportion of variance statistics for level 2 until we have fixed our level 1 model. (See Raudenbush and Bryk 2002, p. $149-152$ for a discussion.)
} 
reported in Models 1 and 2, linked to our core hypothesis, remain consistent throughout our subsequent analyses. The direction, magnitude and statistical significance of the main findings in Models 1 through 3 are little altered by the inclusion of country-level variables and controls in expanded models.

In Model 4, we add a country-level control for log GDP/capita and controls for world regional location. The standard measure of socio-economic development shows a modest positive relationship with student centrism, but one that disappears with the addition of other controls. This is a striking indication that student-centrism is not simply a product of national economic and social modernization, and the immediate interests associated with development. It reflects a much more global cultural change. Across our models, the world regional dummy variables show fairly unstable relationships with student centrism; their significance depends on which substantive core variables are included.

Model 5 examines our second main hypothesis, that national linkages to modern world society increase the degree of student-centeredness in textbooks. We look for the relationship between (log) national memberships in international nongovernmental organizations and student centrism. The linkage variable shows a significant effect in Model 4 - one that eliminates the positive association with log GDP/capita.

We turn now to our third main hypothesis, suggesting that countries with more political, cultural, and economic individualism show higher levels of student centrism. Model 6 incorporates our overall national-level index of individualism. This measure, as noted above, puts together highly correlated indicators of national democracy, the prevalence of the field of psychology, and capitalist ideology. The index shows a significant positive association, as hypothesized. We note that in analyses not reported here the psychology and economic ideology measures show significant positive associations when entered individually with controls for GDP/capita (log) and regional differences, while the democracy score has a positive but insignificant one. 
Overall, our results show substantial support for each of our core hypotheses, net of other factors as shown in Model 7. The model explains $27 \%$ of the country-level variation in student centrism. Studentcentrism rises over time with relevant global emphases, and with national links to global society. It also tends to be higher in countries characterized by more individualism. Importantly, socio-economic development has an insignificant association. This finding runs counter to earlier modernization literatures that strongly emphasize economic development as the driving force in producing cultural change. The growing centrality of the student in textbooks reflects global and national cultural and political factors that have a variety of roots, including economic ones, but these emphases do not principally reflect national economic development (see Thornton 2005 for a related discussion).

Models 4-7 also examine potential world regional effects. The West (the reference group) does not stand out with individualism controlled. Latin America and the mixed "Other" group (Sub-Saharan Africa and Asia) show unhypothesized high levels of student centrism. Further research might show that some of these educational systems - domestically weak - are exceptionally penetrated by the student centrism strongly supported in world educational culture and institutions.

Further Explorations: To strengthen our findings, we conducted a good many further analyses, exploring alternative ideas and arguments. We briefly outline these here.

First, we considered the possibility that contemporary global competitive pressures for educational achievement might have lowered student-centrism, and increased educational foci on required knowledge rather than student interests. So we examined a count of national participation in the current international testing regime (i.e., PISA and IEA tests) and found no association. Second, we considered the possibility that the overall massification of the world's educational systems generates a sort of lowest-commondenominator student-centeredness. We found no link between student-centrism and cross-national variations in secondary (or tertiary) educational enrollments. 
Third, we considered whether a country's human rights record, or potential proclivity towards ethnic conflict through ethno-linguistic diversity, influences the level of student-centrism in textbooks. Neither human rights violations nor ethno-linguistic fractionalization showed an association. Correlated measures of aid and trade dependency (measured by official development aid per capita, trade as a percent of GDP, and gross foreign direct investment) were also insignificant. Our findings suggest broad cultural penetration and influence at work, rather than narrow economic dependencies.

Fourth, we considered additional textbook-level controls. Books vary in the extent to which they depict society as national or international, which could be associated with levels of student-centrism, but a control for the extent to which a book discusses international issues showed insignificant effects. In addition, as mentioned earlier, we began our analyses using a control for the textbook's publication date. Publication date has similar results as the "global individualism index," and it seems likely that historical time works as a proxy for shifts in the nature of individualism and the status of children worldwide. In addition to our theoretical rationale for moving to a substantive measure in place of time, statistical evidence also suggest a model with the "global individualism index" is slightly better than a model with publication date. ${ }^{8}$ Lastly, in Models 2-7 the status of the publisher is inconsequential.

\section{Discussion and Conclusion}

We characterize social science textbooks by their student-centrism, on eight indicators that form a coherent measure. We find substantial rises over time, reflecting changed world models. The increases

\footnotetext{
${ }^{8}$ It is difficult to compare non-nested models, but we considered three pieces of evidence to assess the relative fit of publication date versus global individualism index. First, the deviance statistic for the overall model is lower using our global individualism index. Second, the index explains slightly more variation in the outcome relative to an empty model. Third, if we include both publication date and the global individualism index in the final model, publication date is insignificant, while the index shows a slightly significant positive one. The two variables are highly collinear so we do not leave both in our final model.
} 
seem to be intensified by the often-noted global shift in instruction away from history to social studies and civics, and by the increased foci of curricula on social issues and problems of interest to the student. We also find clear evidence that student-centrism is highest in countries with more social, political and economic individualism. Finally, we find evidence that linkage to the wider world has an independent and positive association with student-centrism.

Taken as a whole, these findings suggest the importance of globally dominant liberal models within which the student is seen as a person with empowered social standing and the capacity to build social and economic change. The changes we find cut across national boundaries, and show little influence of local perspectives. National curricula must be seen as going on within a world, not simply a national, society. And societies most embedded within world society and its preferred models of socialization are most likely to change.

Second, the global dynamic spreads as a cultural force, reflecting a global educational ideology. Doctrines of great professional and cultural standing are involved, and there is little principled opposition to student-centrism and "learning to learn." Naturally, there is much loose coupling in practice, and everywhere in the world one can find forms of instruction reflecting the most traditional notions of cultural and teacher authority. The striking observation is how much student-centrism has gained global authority as ideology, far over and above local practices. Like democracy, human equality, and other dominant modern themes, it is a core element with hegemonic legitimacy. Note that the hegemony involved does not work through trade or aid dependencies, or even through economic development. The links that count are cultural and political.

To be sure, individualism, liberalism, capitalism and democracy have been conceptualized as mutually reinforcing structures and ideologies. But the "varieties of capitalism" literature clearly shows that capitalist ideologies are compatible with more statist or authoritarian regimes as well as with liberal ones. 
At both national and world levels, one can imagine a triumphant capitalist ideology that favored authoritarian educational regimes, not student-centered curricula. Indeed, the critical literature on schooling in capitalist societies often emphasizes the school as conditioning students for conformity to social norms (Spring 1980; Bowles and Gintis 1976; Willis 1981). None of this literature imagined that the needs of a capitalist economy would lead to a more expanded and positive view of active learning. Obviously, broad cultural changes have also changed contemporary models of economic, as well as political and social, development.

Western countries are more student-centered than Eastern European ones. But Latin American textbooks are even more student-centered, making it difficult to advance explanations that privilege national capitalist ideologies. If economic ideologies are consequential, they are very broad ones, operating on a global level and closely linked to more general political and cultural themes.

Our findings show that societies change in the qualities they seek to foster in children. In traditional settings, students are subordinated to authoritative texts, with the teacher perhaps simply an instrument. In contemporary education - more liberal, more globalized, and more post-modern - the student becomes the core project of education. Traditional canons weaken, the authoritative teacher becomes a facilitator or resource person, and the student's choices and interests become central.

In studying the curriculum, we seek to make a case for a broader sociology of education - one linked to both cultural and political sociology. Varying global and national visions of what students should learn are built in the intended curriculum. Nation-specific approaches need to be broadened to handle isomorphic change at the global level. Such changes reflect globally changed notions of progress and of the way school knowledge links to it. For many decades, the school-to-progress link has been taken for granted at individual and national levels. Our findings imply that current doctrines formulate connections at more global levels, and that at these levels the empowered student is envisioned as central. The 
production of a world society built on the choices and capacities of students involves a greatly expanded and globalized notion of individual citizenship, and is a matter of consequence not only the sociology of education, but also for political and cultural sociology. 


\section{References}

Ariès, P. 1962. Centuries of Childhood. New York: Vintage Books

Arum, R. 2003. Judging School Discipline: The Crisis of Moral Authority. Cambridge: Harvard University Press.

Baker, D. and G. LeTendre. 2005. National Differences, Global Similarities: World Culture and the Future of Schooling. Stanford: Stanford University Press.

Benavot, A. and N. Resh. 2001. "The Social Construction of the Local School Curriculum: Patterns of Diversity and Uniformity in Israeli Junior High Schools". Comparative Education Review. 45, 4: 504536.

Benavot, A., in collaboration with M. Amadio. 2005, A Global Study of Intended Instructional Time and Official School Curricula, 1980-2000. UNESCO background report. Geneva: International Bureau of Education.

-- and C. Braslavsky, eds. 2006. School Curricula for Global Citizenship. Hong Kong: Comparative Education Research Center,University of Hong Kong/Springer.

Bloom, A. 1987. The Closing of the American Mind. New York: Simon and Schuster.

Boli-Bennett, J. and J.W. Meyer. 1978. "The Ideology of Childhood and the State: Rules Distinguishing Children in National Constitutions, 1870-1970." American Sociological Review 43, 6, December 1978: 797-812.

Boli, J. and G.M. Thomas. 1999. Constructing World Culture: International Nongovernmental organizations since 1875. Stanford, CA: Stanford University Press.

-- and M. Elliott. 2008. "Façade Diversity: The Individualization of Cultural Difference. International Sociology 23, 4:540-60.

Bowles, S. and H. Gintis. 1976. Schooling in Capitalist America. New York: Basic Books.

Bromley, P., Meyer, J.W. and F. Ramirez. 2011, Forthcoming. "Environnmentalism in Social Science Textbooks: Cross-National Trends." Comparative Education Review

Carrithers, M., Collins, S. and S. Lukes, eds. 1985. The Category of the Person: Anthropology, Philosophy, History. Cambridge, UK: Cambridge University Press.

Chabbott, C. 2003. Constructing Education for Development: International Organizations and Education for All. New York: Routledge/Falmer.

Cohen, P. 1962. A Calculating People: The Spread of Numeracy in Early America. Chicago: University of Chicago Press.

Dreeben, R. 1968. On What is Learned in School. Reading, Mass.: Addison Wesley. 
Durkheim, E. [1911] 1965. Elementary Forms of Religious Life. New York: Free Press.

Elliott, M. 2008. A Cult of the Individual for a Global Society: The Development and Worldwide Expansion of Human Rights Ideology. Unpublished doctoral dissertation, Department of Sociology, Emory University.

Frank, D, and J.W. Meyer. 2007. "University Expansion and the Knowledge Society." Theory and Society 36: 287-311.

--, Meyer, J.W. and D. Miyahara. 1995. "The Individualist Polity and the Centrality of Professionalized Psychology." American Sociological Review 60, 3: 360-377.

-- and J. Gabler. 2006. Reconstructing the University: Worldwide Shifts in

Academia in the $20^{\text {th }}$ Century. Stanford: Stanford University Press.

Goodman, P. 1960. Growing up Absurd. New York: Random House.

Habermas, J. 1987. The Theory of Communicative Action. Vol 2. Boston: Beacon.

Heritage Foundation. 2011. Index of Economic Freedom. Accessed on December 15, 2010 at: http://www.heritage.org/index/.

Illich, I. 1971. Deschooling Society. New York: Harrow Books.

Inkeles, A. and D. Smith. 1974. Becoming Modern: Individual Change in Six Developing Countries. Cambridge: Harvard University Press.

Jakobi, A. 2009. International Organizations and Lifelong Learning: From Global Agendas to Policy Diffusion. Houndsmill, Basingstoke: Palgrave Macmillan

Koo, J.W. and F.O. Ramirez. 2009. "National Incorporation of Global Human Rights: Worldwide Expansion of National Human Rights Institutions, 1966-2004. Social Forces 87, 3:1321-54.

Lerner, D. 1963 The Passing of Traditional Society. Glencoe, Ill: Free Press.

Lie, J. 2004. Modern Peoplehood. Cambridge, MA: Harvard University Press.

Marshall, M. 2007. Polity IV Project: Political Regime Characteristics and Transitions, 1800-2007. Washington, D.C.: George Mason University.

Meyer, J.W. 1977. "The Effects of Education as an Institution.” American Journal of Sociology. 83, 1: 55-77.

--, Boli, J., Thomas, G.M. and F.O. Ramirez. 1997. "World Society and The Nation-state." American Journal of Sociology. 103, 1: 144-181.

--, Ramirez, F.O. and Y.N. Soysal. 1992a "World Expansion of Mass Education, 1870-1970." Sociology of Education 65, 2: 128-149. 
--, Kamens, D., Benavot, A, Cha, Y.K. and S.Y. Wong. 1992b. School Knowledge for the Masses: World Models and National Primary Curricular Categories in the Twentieth Century. London: Falmer Press.

--, Bromley, P. and F.O. Ramirez. 2010. "Human Rights in Social Science Textbooks: Cross-National Analyses, 1975-2006." Sociology of Education 83: 111-134.

-- and R. Jepperson. 2000. "The "Actors" of Modern Society: The Cultural Construction of Social Agency." Sociological Theory. 18,1: 100-120.

Ramirez, F.O. 1989. "Reconstituting Children: Extension of Personhood and Citizenship." Pp. 143-165 in David Kertzer and K. Warner Schaie, eds., Age Structuring in Comparative Perspective. Lawrence Erlbaum Associates, Inc. Publishers.

--. 2006. "From Citizen to Person: Rethinking Education as Incorporation" pp. 367-388 in David Baker and Alexander Wiseman, eds. The Impact of Comparative Education Research on Neo-Institutional Theory. Oxford, Elsevier Science.

--, Suárez, D. and J.W. Meyer. 2006. "The Worldwide Rise of Human Rights Education." Pp. 35-52 in A. Benavot and C. Braslavsky, eds., School Curricula for Global Citizenship. Hong Kong: Comparative Education Research Center,University of Hong Kong/Springer.

Raudenbush, S. and A. Bryk. 2002. Hierarchical Linear Models: Applications and Data Analysis Methods, Second Edition. Thousand Oaks: Sage.

Ravitch, D. 1987. "Tot Sociology: On What Happened To History in the Grade Schools" The American Scholar Summer: 343-354.

Rosenmund, M. 2006. "The Current Discourse on Curriculum Change. Pp. 173-194 in A. Benavot and C. Braslavsky, eds., School Curricula for Global Citizenship. Hong Kong: Comparative Education Research Center, University of Hong Kong/Springer.

Schofer, E. and J.W. Meyer. 2005. "The World-Wide Expansion of Higher Education in the Twentieth Century." American Sociological Review 70, 6: 898-920.

Spring, J. 1980 Educating the Worker-Citizen: The Social, Economic, and Political Foundations of Education. New York: Longman.

Suárez, D. 2007. "Education Professionals and the Construction of Human Rights Education." Comparative Education Review 51:48-70.

Swanson, G. 1967. Religion and Regime: A Sociological Account of the Reformation. Ann Arbor: University of Michigan Press.

Thornton, A. 2005. Reading History Sideways: the Fallacy and Enduring Impact of the Developmental Paradigm on Family Life. Chicago: University of Chicago Press.

Torney-Purta, J., Lehmann, R. Oswald, H. and W. Schulz. 2001. Citizenship and Education in TwentyEight Countries: Civic Knowledge and Engagement at Age Fourteen. Amsterdam: International Association for the Evaluation of Educational Achievement. 
Tseng, S-Y. 1966. A History of Chinese Examination System, Taipei: Taiwan Xue Sheng Shu Dian (in Chinese).

Universal Declaration of Human Rights. 1948. G.A. res. 217A (III), U.N. Doc A/810 at 71.

United Nations. 1989. Convention on the Rights of the Child. http://www2.ohchr.org/english/law/crc.htm

Willis, P. 1981. Learning to Labor: How Working Class Kids Get Working Class Jobs. New York: Columbia University Press.

Wong, S.Y. 1991. "The Evolution of Social Science Instruction, 1900-86." Sociology of Education 64: 33-47.

World Bank. 2008. World Development Indicators. Washington, DC: World Bank.

Yearbook of International Organizations, various years. Munich, Germany: Union of International Associations and K G Saur Verlag.

Zborowski, M. 1995. Life is With People: The Culture of the Shtetl. Second ed. New York: Schocken Books.

Zelizer, V. 1985. Pricing the Priceless Child: The Changing Social Value of Children, Princeton University Press. 
Table 1. Changes Over Time in Properties of Textbooks

\begin{tabular}{|c|c|c|c|c|c|}
\hline \multirow[b]{2}{*}{ A. Indicators of Student Centrism (means) } & \multirow[t]{2}{*}{$\begin{array}{c}1970-1984 \\
(n=105)\end{array}$} & \multicolumn{2}{|c|}{$\begin{array}{c}1985-1994^{\mathrm{a}} \\
(\mathrm{n}=154)\end{array}$} & \multicolumn{2}{|c|}{$\begin{array}{c}1995-2008^{b} \\
(n=274)\end{array}$} \\
\hline & & & & & \\
\hline Pictures, esp. Child-Friendly (0-3) & 1.276 & 1.494 & $* *$ & 2.084 & $* * * *$ \\
\hline Assignments for Students (0-2) & 1.305 & 1.500 & $* *$ & 1.887 & $* * * *$ \\
\hline Projects for Students (0-2) & 0.200 & 0.438 & $* * * *$ & 0.686 & $* * * *$ \\
\hline Role-Playing for Students (0-2) & 0.114 & 0.234 & $* *$ & 0.473 & $* * * *$ \\
\hline Open-Ended Questions for Students (0-3) & 1.238 & 1.506 & $* *$ & 2.102 & $* * * *$ \\
\hline Text in Expanding Environments Format (0-3) & 0.433 & 0.370 & & 0.620 & $* * *$ \\
\hline Amount Children Discussed in Text (0-5) & 0.845 & 0.903 & & 1.201 & $* *$ \\
\hline Mentions Children's Rights (0-1) & 0.231 & 0.149 & $* *$ & 0.311 & $* * * *$ \\
\hline Student-Centrism Index & 0.786 & 0.994 & $* * *$ & 1.408 & $* * * *$ \\
\hline \multicolumn{6}{|l|}{ B. Student-Centrism Index Score by Region ${ }^{c}$} \\
\hline Western Europe \& North America & 0.813 & 1.023 & $* *$ & 1.497 & $* * * *$ \\
\hline Eastern Europe & 0.753 & 0.686 & & 1.122 & $* * * *$ \\
\hline Middle East \& North Africa & 0.451 & 0.643 & & 1.039 & $* *$ \\
\hline Latin America \& Caribbean & 0.880 & 1.130 & & 1.630 & $* * *$ \\
\hline Other Non-West & 0.799 & 1.143 & $*$ & 1.503 & $* * * *$ \\
\hline \multicolumn{6}{|l|}{ C. Other Textbook-Level Indicators } \\
\hline Percent History (vs. Social Studies or Civics) & 0.476 & 0.461 & & 0.347 & $* * *$ \\
\hline Percent Mentioning Social Science Issues & 0.124 & 0.208 & $* *$ & 0.296 & $* *$ \\
\hline
\end{tabular}

$* * * * \mathrm{p}<.001, * * * \mathrm{p}<.01, * * \mathrm{p}<.05, * \mathrm{p}<.1$, one-tailed tests

Notes: a) Significance indicates t-test comparing difference between periods 1 and 2. b) Significance indicates t-test comparing difference between periods 2 and 3. c) Total number of books is 533, total number of countries is 74 . Number of books in each region over time are: West $(53,57,58)$, Eastern Europe (29, 30, 57), Middle East and North Africa (4, 4, 18), Latin America and Caribbean (8, 22, 35), and Other Non-West $(11,41,106)$. 
Table 2. Hierarchical Linear Model Analyses of Student Centrism Index ${ }^{a, b, c}$

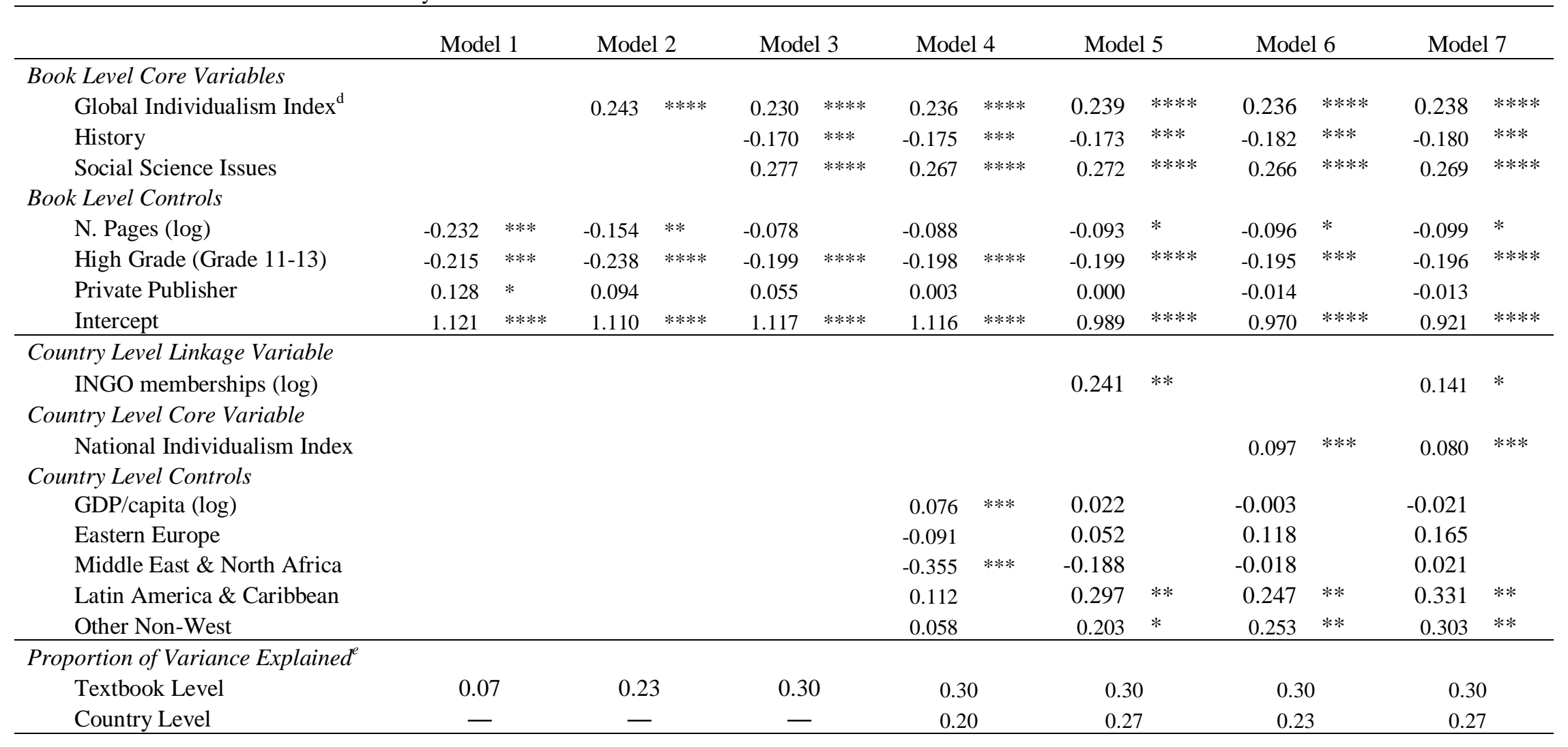

$* * * * \mathrm{p}<.001, * * * \mathrm{p}<.01, * * \mathrm{p}<.05, *<.1$, one-tailed tests

Notes: a) Reporting robust standard errors. b) N. at level 1 is 526, N. at level 2 is 73. c) All book level and continuous country level variables are grand mean centered. The reference group for world regions is Western. d) The "Global Individualism Index" is a world measure, but enters the statistical analyses as a property of textbooks. e) Proportion of variance explained at each level is relative to an empty model with no predictors. 


\section{fiempo de descubrir La cruzada de los niños}

En Polonia, en el año treinta y nueve, se libró una batalla muy sangrienta que convirtió en ruinas y desiertos las ciudades y aldeas.

Allí perdió la hermana al hermano.

$\mathrm{Y}$, entre fuego y escombros, a sus padres los hijos no encontraron.

No llegaba ya nada de Polonia. Ni noticias ni cartas.

Pero una extraña historia, en los países del Este circulaba.

La contaban en una gran ciudad, $y$ al contarla nevaba.

Hablaba de unos niños que, en Polonia, partieron en cruzada.

Por los caminos, en rebaño hambriento, los niños avanzaban.

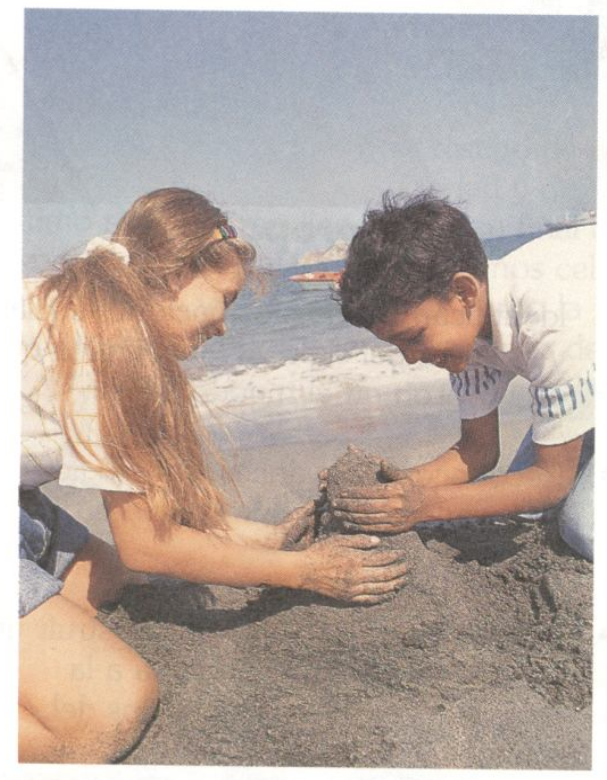

\section{4}

Figure 1: Student-centered middle school civics text from Guatemala.

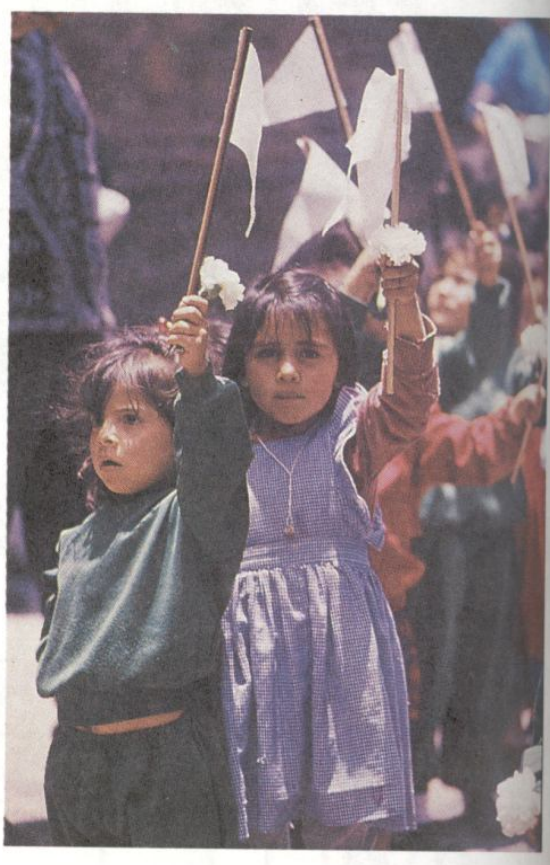

Se les iban uniendo muchos otros al cruzar las aldeas bombardeadas. De batallas y negras pesadillas querian escapar para llegar, al fin, a algún país en el que hubiera paz.

No faltaban la fe ni la esperanza, perosi les faltaba carne y pan.

Quien les negó su amparo y fue robado después, nada les puede reprochar. Mas nadie acuse al pobre que a su mesa no los hizo sentar.

Para cincuenta niños hace falta mucha harina: no basta la bondad.

Fragmento de "La cruzada de los niños", de Bertolt Brecht (alemán, 
work out a constitution for the new party. Kenyatta was elected its first President while he was still in detention. This was rejected by the colonial authorities and Kenyatta's name was dropped.

To ensure that the party activities did not stall, James Gichuru was made President, Oginga Odinga (Vice-president), Tom Mboya (Secretary General), Arthur Ochwada (Assistant Secretary General). Mwai Kibaki who by then was teaching at Makerere University was persuaded to leave his job and took up the job of Executive Officer.

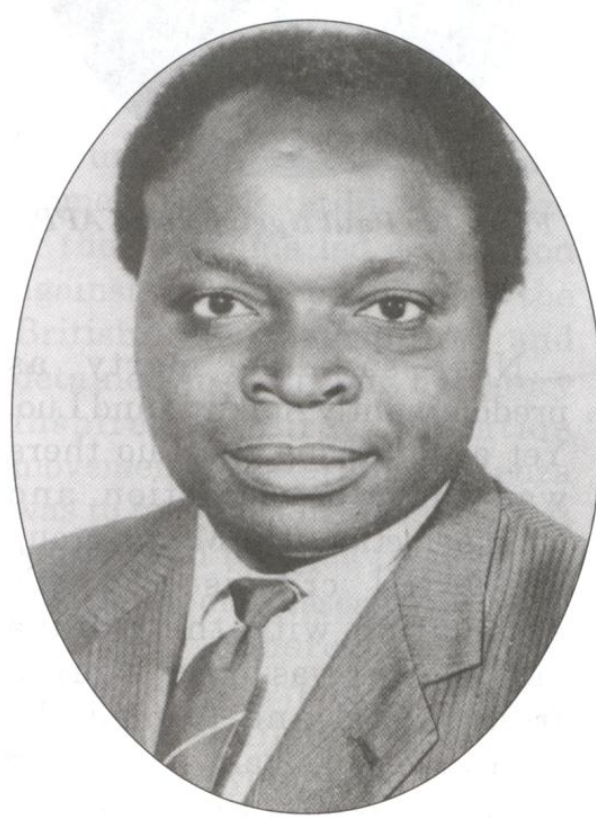

Fig. 5.12: Mwai Kibaki; became executive officer of KANU.
Daniel Moi and Ronald Ngala were made committee officials of the party but declined to take up the offer. Both were out of the country then.

Some nationalist leaders viewed KANU as being too radical, urban oriented and dominated by the two large ethnic groups, namely the Agikuyu and the Luo. The minority groups felt threatened and left.

\section{Kenya African Democratic Party (KADU)}

In June, 1960, the leaders of minority ethnic groups such as the Kalenjin, Maasai, Coast communities, people of North Eastern province and the Abaluyia of Western province met at Ngong and formed KADU. Ronald Ngala, Daniel Arap Moi, Masinde Muliro and Justus ole Tipis were the KADU leaders. Its aim was to check Kikuyu and Luo dominance in independent Kenya.

KADU pressed for Majimbo or federal kind of constitution while KANU preferred a unitary constitution. The first elections on a common roll for all races were held in 1961. KANU won 19 seats and KADU 11. Three seats were won by eight other parties. KANU was supposed to form the government but refused to do so while Kenyatta was still in detention.

Figure 2: Book with Low Student Centrism from Kenya. 
Appendix A: Count of Textbooks by Country and Time Period (n. countries $=74, n$. textbooks $=533$ ) Western Europe and North America

\begin{tabular}{lcccc}
\hline \hline & $1970-1984$ & $1985-1994$ & $1995-2006$ & Total \\
\hline Australia & 2 & 4 & 2 & 8 \\
Austria & 5 & 4 & 3 & 12 \\
Belgium & 2 & 3 & 2 & 7 \\
Canada & 4 & 4 & 3 & 11 \\
Denmark & 1 & 2 & 2 & 5 \\
Finland & 7 & 6 & 1 & 14 \\
France & 5 & 5 & 4 & 14 \\
Germany & 2 & 2 & 2 & 6 \\
Greece & 1 & 2 & 2 & 5 \\
Ireland & 3 & 2 & 4 & 9 \\
Italy & 1 & 2 & 2 & 5 \\
Norway & 2 & 2 & 2 & 6 \\
Portugal & 2 & 2 & 2 & 6 \\
Spain & 3 & 2 & 9 & 14 \\
Sweden & 2 & 2 & 2 & 6 \\
Switzerland & 2 & 2 & 1 & 5 \\
USA & 2 & 6 & 4 & 12 \\
United Kingdom & 7 & 5 & 11 & 23 \\
\hline Total & 53 & 57 & 58 & 133
\end{tabular}

Eastern Europe

\begin{tabular}{lcccc}
\hline \hline & $1970-1984$ & $1985-1994$ & $1995-2006$ & Total \\
\hline Armenia & 0 & 1 & 6 & 7 \\
Belarus & 0 & 1 & 3 & 4 \\
Bosnia and & & & & 8 \\
Herzegovina & 0 & 1 & 7 & 16 \\
Bulgaria & 8 & 4 & 4 & 2 \\
Croatia & 0 & 1 & 1 & 4 \\
Czechoslovakia & 3 & 1 & 0 & 5 \\
Georgia & 0 & 0 & 5 & 3 \\
Latvia & 0 & 0 & 3 & 2 \\
Macedonia & 0 & 1 & 1 & 5 \\
Romania & 1 & 2 & 2 & 27 \\
Russia & 0 & 4 & 23 & 3 \\
Slovenia & 0 & 1 & 2 & 25 \\
USSR & 14 & 11 & 0 & 5 \\
Yugoslavia & 3 & 2 & 0 & 116 \\
\hline Total & 29 & 30 & 57 &
\end{tabular}


Middle East and North Africa

\begin{tabular}{lcccc}
\hline \hline & $1970-1984$ & $1985-1994$ & $1995-2006$ & Total \\
\hline Iran & 2 & 2 & 0 & 4 \\
Morocco & 0 & 1 & 2 & 3 \\
Palestine & 0 & 0 & 7 & 7 \\
Syria & 0 & 0 & 2 & 2 \\
Tunisia & 0 & 0 & 3 & 3 \\
Turkey & 2 & 1 & 4 & 7 \\
\hline Total & 4 & 4 & 18 & 26
\end{tabular}

Latin America \& Caribbean

\begin{tabular}{lcccc}
\hline \hline & $1970-1984$ & $1985-1994$ & $1995-2006$ & Total \\
\hline Argentina & 1 & 2 & 4 & 7 \\
Bolivia & 0 & 4 & 0 & 4 \\
Colombia & 2 & 6 & 0 & 8 \\
Costa Rica & 0 & 0 & 4 & 4 \\
Ecuador & 0 & 1 & 4 & 5 \\
El Salvador & 0 & 0 & 1 & 1 \\
Guatemala & 0 & 0 & 2 & 2 \\
Guyana & 0 & 0 & 1 & 1 \\
Jamaica & 0 & 0 & 2 & 2 \\
Mexico & 1 & 3 & 6 & 10 \\
Nicaragua & 0 & 1 & 0 & 1 \\
Panama & 0 & 1 & 2 & 3 \\
Peru & 4 & 3 & 7 & 14 \\
Trinidad \& Tobago & 0 & 0 & 1 & 1 \\
Venezuela & 0 & 1 & 1 & 2 \\
\hline Total & 8 & 22 & 35 & 65
\end{tabular}


Other Non-West

\begin{tabular}{lcccc}
\hline \hline & $1970-1984$ & $1985-1994$ & $1995-2006$ & Total \\
\hline Ethiopia & 0 & 2 & 0 & 2 \\
Ghana & 0 & 12 & 2 & 14 \\
India & 3 & 2 & 19 & 24 \\
Indonesia & 0 & 0 & 12 & 12 \\
Israel & 1 & 3 & 0 & 4 \\
Japan & 2 & 1 & 2 & 5 \\
Kenya & 0 & 6 & 4 & 10 \\
Malawi & 0 & 0 & 2 & 2 \\
Namibia & 0 & 2 & 0 & 2 \\
Nepal & 0 & 0 & 7 & 7 \\
North Korea & 0 & 1 & 2 & 3 \\
PR China & 0 & 1 & 1 & 2 \\
Pakistan & 0 & 0 & 3 & 3 \\
Philippines & 0 & 4 & 2 & 6 \\
Singapore & 0 & 1 & 0 & 1 \\
South Africa & 2 & 2 & 25 & 29 \\
South Korea & 3 & 3 & 4 & 10 \\
Taiwan & 0 & 1 & 12 & 13 \\
Tanzania & 0 & 0 & 8 & 8 \\
Uganda & 0 & 0 & 1 & 1 \\
\hline Total & 11 & 41 & 106 & 158
\end{tabular}

